\title{
Distribution and Growth of Grey Triggerfish, Balistes capriscus (Family: Balistidae), in Western Gulf of Guinea
}

\author{
J. Aggrey-Fynn \\ Department of Fisheries \& Aquatic Sciences, University of Cape Coast, Cape Coast, Ghana \\ E-mail:jafynn@yahoo.com
}

\begin{abstract}
The grey triggerfish, Balistes capriscus, resource had declined for nearly two decades in West African waters; its distribution and growth remain to be reported after late 1980s. In order to fill this gap, specimens were collected during small pelagic fish stock assessment surveys in 2005 in coastal waters of Benin, Togo, Ghana and La Côte d'Ivoire (Western Gulf of Guinea) from 17 out of 165 swept-area hauls in depths range of $23-60 \mathrm{~m}$. The modal size classes were $27.0-31.9 \mathrm{~cm}$ and $32.0-36.9 \mathrm{~cm}$. The age classes were determined by interpreting growth rings on sections of first dorsal spines. Estimates of theoretical growth in length were obtained by fitting the observed length-at-age data to the standard form of von Bertalanffy growth equation. The estimated $L_{\infty}$ for $B$. capriscus was $45.1 \pm 1.4 \mathrm{~cm}$ and the growth rate, $K$, was $0.21 \mathrm{yr}^{-1}$. The phi prime (Ö') growth performance obtained was 2.63, which is comparable to that obtained in the 1980s on the same fish species in waters of Senegal, La Côte d'Ivoire and Ghana. The results suggest that the growth and distribution of grey triggerfish in the Western Gulf of Guinea had not changed, in spite of the apparent disappearance of the fish species in many areas of the West African coastal waters for nearly two decades.
\end{abstract}

\section{Introduction}

The grey triggerfish, Balistes capriscus, is a tropical reef fish which has a very wide bathymetric distribution (Ofori-Adu \& Koranteng, 1993). The species occurs near the bottom as well as near the surface of the sea (usually $15-50 \mathrm{~m}$ depth in coastal waters), and so it is caught not only by bottom trawl nets but also by purse seine nets (Essuman \& Diakité, 1990; Ofori-Adu, 1987, 1994). The fish species is distributed in both eastern and western parts of the Atlantic Ocean (Sazonov \& Galaktionova, 1987), English waters (Dul ić et al., 1997), along the Mediterranean Sea, Azores, Canary Islands (Lobel \& Johannes, 1980), Islands of Madeira and the coast of West Africa to Angola (Svetovidov, 1964 cited by Sazonov \& Galaktionova, 1987; Longhurst \& Pauly, 1987; Koranteng et al., 1996). Its distribution in the Western Atlantic is from Nova Scotia to Argentina (Briggs, 1958 cited by Moore, 1967; Sazonov \& Galaktionova, 1987). It is reported that triggerfish species was at maximum abundance at the end of the 1970s in the Gulf of Guinea and at the beginning of the 1980s in the Canary current (Caverivière, 1982; Stromme et al., 1982).

There are reports that two separate stocks of grey triggerfish used to occur in the Gulf of Guinea - the eastern stock which occurred off Ghana and the western stock off Guinea Bissau and Guinea (Stromme et al., 1982; Stromme, 1983; Mensah \& Quaatey, 2002). The biomass of the eastern stock was estimated to be 500,000 and 140,000 tons in 1981 and 1986, respectively (Stromme et al., 1982). The maximum size of grey triggerfish in coastal waters of Ghana is $350 \mathrm{~mm} F L$ and the modal size is $18.0-23.0 \mathrm{~cm} F L$ in August (OforiDanson, 1981). Various $L_{\infty}$ of B. capriscus in the Gulf of Guinea are presented in Caverivière (1982) and Koranteng (1998). The fish species drastically declined from 18,283 tonnes in 1987 to 12 tonnes in 2002 in Ghanaian waters, and recent reports (Mehl et al., 2004, 2005; FAO, 2006) show that one tonne of the fish species were captured in 2004 in Ghana.

The objectives of the present study were to find out how the distribution and growth of grey triggerfish had changed after nearly two decades of apparent disappearance in the Western Gulf of Guinea. This is an aspect of studies to find out the possible reasons for the collapse of grey triggerfish resource in West Africa.

\section{Materials and methods}

\section{Study sites}

Benin, Togo, Ghana and La Cote d'Ivoire waters (Western Gulf of Guinea $-6^{\circ} 28^{\prime} \mathrm{N} 2^{\circ} 36^{\prime} \mathrm{E}, 6^{\circ} 51^{\prime} \mathrm{N}, 5^{\circ}$ $18^{\prime} \mathrm{W}$ ) in West Africa were surveyed for grey triggerfish distribution during the small pelagic fish stock assessment (Mehl et al., 2005). The survey routes comprised of trawling, plankton and hydrographic stations. For the purpose of this study only trawl stations are shown in Fig. 1. The cruise course and trawl stations were pre-determined in previous similar surveys in the Western Gulf of Guinea in 1999, 2000, 2002, and 2004.

\section{Catch and biological data acquisition}

Catch and biological data were collected for Balistes (Fig. 1) and total length (TL mm) and body weight (W grams) were recorded for each individual sampled. A total of 165 swept-area hauls were taken in Benin, Togo, Ghana and La Côte d'Ivoire trawlable fishing grounds, between 20 and $100 \mathrm{~m}$ depth. The triggerfish 
specimens were collected when they occurred in the hauls at various stations during the survey. First dorsal spines were extracted from individual specimens and stored dry in sample bottles.



Fig. 1. Distribution of triggerfish in Western Gulf of Guinea in May $2005(\bullet:$ stations with Balistes capriscus catch; $\diamond$ : stations with Balistes punctatus catch; +: stations with miscellaneous fish catch other than triggerfish). Offshore depths are $50 \mathrm{~m}, 200 \mathrm{~m}$ and $1000 \mathrm{~m}$. Along shore distance is $1237 \mathrm{~km}$ from west to east ends. Insert is Map of Africa showing western Gulf of Guinea.

\section{Dorsal spine preparations and ageing}

Thin sections $(1 \mathrm{~mm})$ of the dorsal spines were cut with a diamond-edged blade (Isomet ${ }^{\circledR}$ 4000-linear precision saw) at low speed through the centre in a transverse plane perpendicular to the long axis of the spine. Three successive sections were obtained: (i) the first section just above the condyle (the enlarged base of the spine), (ii) second section in the middle portion, and (iii) the third section towards the anterior tip of the spine. Preliminary trials showed that transverse sections of spines from the middle towards the condyle produced much clearer increments than did sections towards the anterior portion. Sections were mounted on a glass slide with a resin.

With a digital camera (Canon ESO) attached to a light microscope at low magnification (50×), slide image was captured and image analyser (Image-Pro ${ }^{\circledR}$ Plus 5.1 software) was used to count annuli and measure radii (Fig. 5). Only light or translucent bands were counted as annuli following the validation of translucent bands in Johnson \& Saloman (1984). Annuli counting were done on the best radius of a stitched-complete spine image. When the increment pattern was not clear, a prominent increment was followed laterally to the closest clear increment sequence. Where annuli were not clear to read, image filters were used to enhance clarity.

The data for length-at-age of 74 Balistes specimens was pooled from Benin, Togo, Ghana and La Côte d'Ivoire, based on the knowledge that the triggerfish in these areas are part of the eastern triggerfish stock (Stromme et al., 1982; Stromme, 1983; Mensah \& Quaatey, 2002) of the Gulf of Guinea. 


\section{Growth investigations}

An estimate of theoretical growth in length was obtained by fitting the observed length-at-age data to the standard form of the von Bertalanffy growth equation (Gayanilo \& Pauly, 1997; FAO-ICLARM, 2006):

$$
\mathrm{L}_{\mathrm{t}}=\mathrm{L}_{\infty}\left[1-\mathrm{e}^{-K}\left(\mathrm{t}-\mathrm{t}_{\mathrm{o}}\right)\right]
$$

where $L_{t}$ is the total length at age $t, L_{\infty}$ the asymptotic length, $K$ the growth coefficient, and $t_{0}$ the theoretical age at zero length.

\section{Back-calculation}

The back-calculations of total lengths at various annuli were obtained by substituting the mean annulus radius into the total length-spine radius relationship.

\section{Growth performance}

The growth performance of grey triggerfish populations in terms of length was compared using the index of Pauly \& Munro (1984):

$$
\varnothing^{\prime}=\log _{10} K+2 \log _{10} L_{\infty}
$$

where $\varnothing^{\prime}$ is the growth performance index, which was used to compare growth of the fish species for different time periods (dominance and collapse periods in the case of triggerfish in Western Gulf of Guinea). Reported values of $K$ and $L_{\infty}$ obtained in various studies in the Gulf of Guinea in the 1980s (Caverivière, 1982; Ofori-Danson, 1989) were used to calculate $\varnothing$ ' for comparison with the estimate obtained in this study.

\section{Results}

Fig. 1 shows the distribution of triggerfish that were caught in the Western Gulf of Guinea during the Fridtjof Nansen Survey 2005. Two species of triggerfish (B. capriscus and B. punctatus) were obtained in waters from Benin to La Côte d'Ivoire. The round plots indicate the stations where the hauls resulted in B. capriscus; the diamond plots indicate the locations where B. punctatus were caught; and the cross plots represent other stations for which miscellaneous other fish species were caught (Fig. 1). In all, 165 stations were trawled along the Western Gulf of Guinea from the Liberia-La Côte d'Ivoire border to the Benin-Nigeria border. Of the 165 total trawl stations, 54 trawls were undertaken between La Côte d'Ivoire and Ghana, 77 trawls between Ghana and Togo, 12 trawls between Togo and Benin, and 22 trawls between Benin and BeninNigeria borders. Grey triggerfish were obtained in 17 of the total of 165 hauls (Fig. 1).

Fig. 2 shows the capture depth range of B. capriscus caught during the survey. The area the fish were caught were represented by distance $(\mathrm{km})$ and the number of Balistes obtained in each area were indicated. In La Côte d'Ivoire waters, 45 grey triggerfish were caught at eight different stations with depth range of 23-60 $\mathrm{m}$. In Ghana, 21 grey triggerfish were caught at five different stations between 25 and $47 \mathrm{~m}$ depth range, while in Togo, 10 grey triggerfish were caught at three different stations with depth range of 35-52 m. Eight grey triggerfish were caught in Benin waters at $32 \mathrm{~m}$ depth in one station. In all, $84 \mathrm{~B}$. capriscus were caught in water depths between $23-60 \mathrm{~m}$ depth from La Côte d'Ivoire to Benin. The highest number (26) of $B$. capriscus was caught off La Côte d'Ivoire at a depth of $36 \mathrm{~m}$ (Fig. 2).



Fig. 2. Distribution, capture depth and Balistes caught in Western Gulf of Guinea in May 2005. Countries bordering Western Gulf of Guinea are shown. 
Fig. 3 shows size distribution of grey triggerfish species caught during the survey. The modal size classes were $27.0-31.9 \mathrm{~cm}$ and $32.0-36.9 \mathrm{~cm}$ where 21 of the fish specimens were obtained in each class. The size class of 52.0-56.9 $\mathrm{cm}$ was the less dominant in the catches of grey triggerfish.

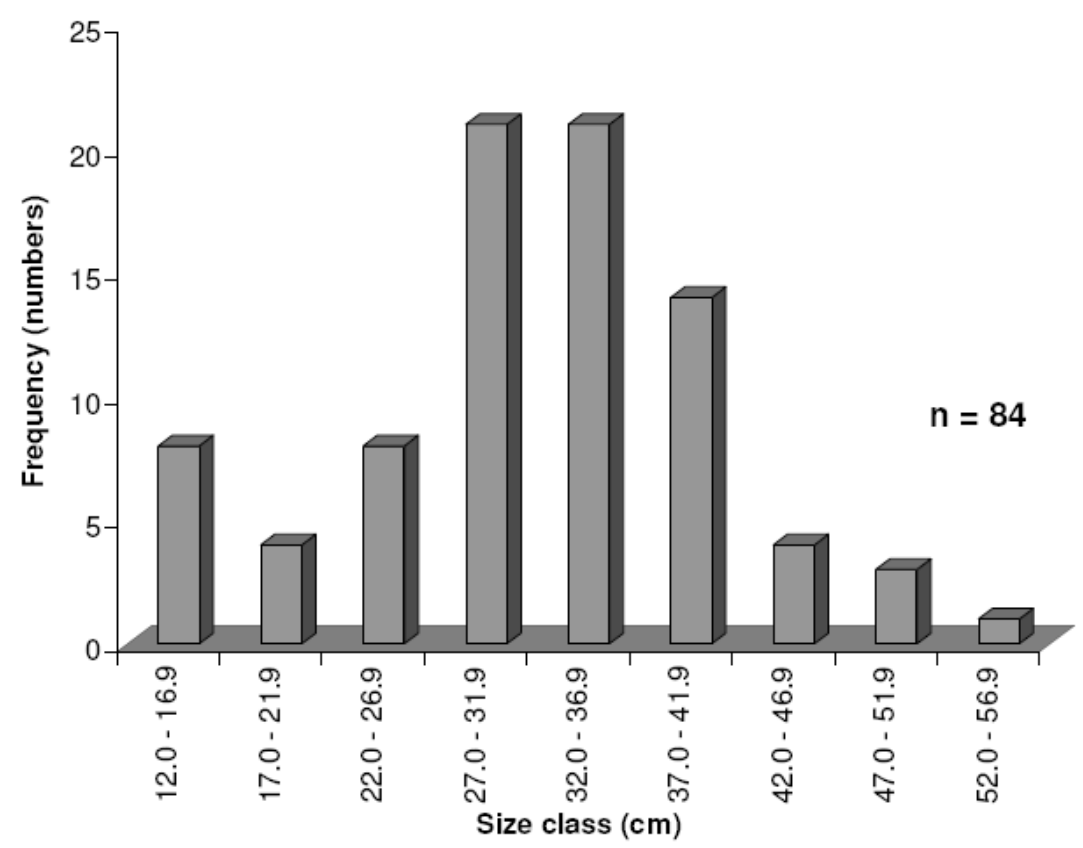

Fig. 3. Size distribution of grey triggerfish in Western Gulf of Guinea, May 2005

\section{Size-weight relationship}

Fig. 4 shows the size-weight graph of B. capriscus in the Western Gulf of Guinea. The size-weight relationship showed a good fit to the exponential curve $\left(\mathrm{R}^{2}=0.9835\right)$.

$$
\mathrm{W}=0.0711 \mathrm{~L}^{2.515}
$$

where $L$ is total length $(\mathrm{cm})$ and $W$ is body weight in grams. The growth in weight was isometric

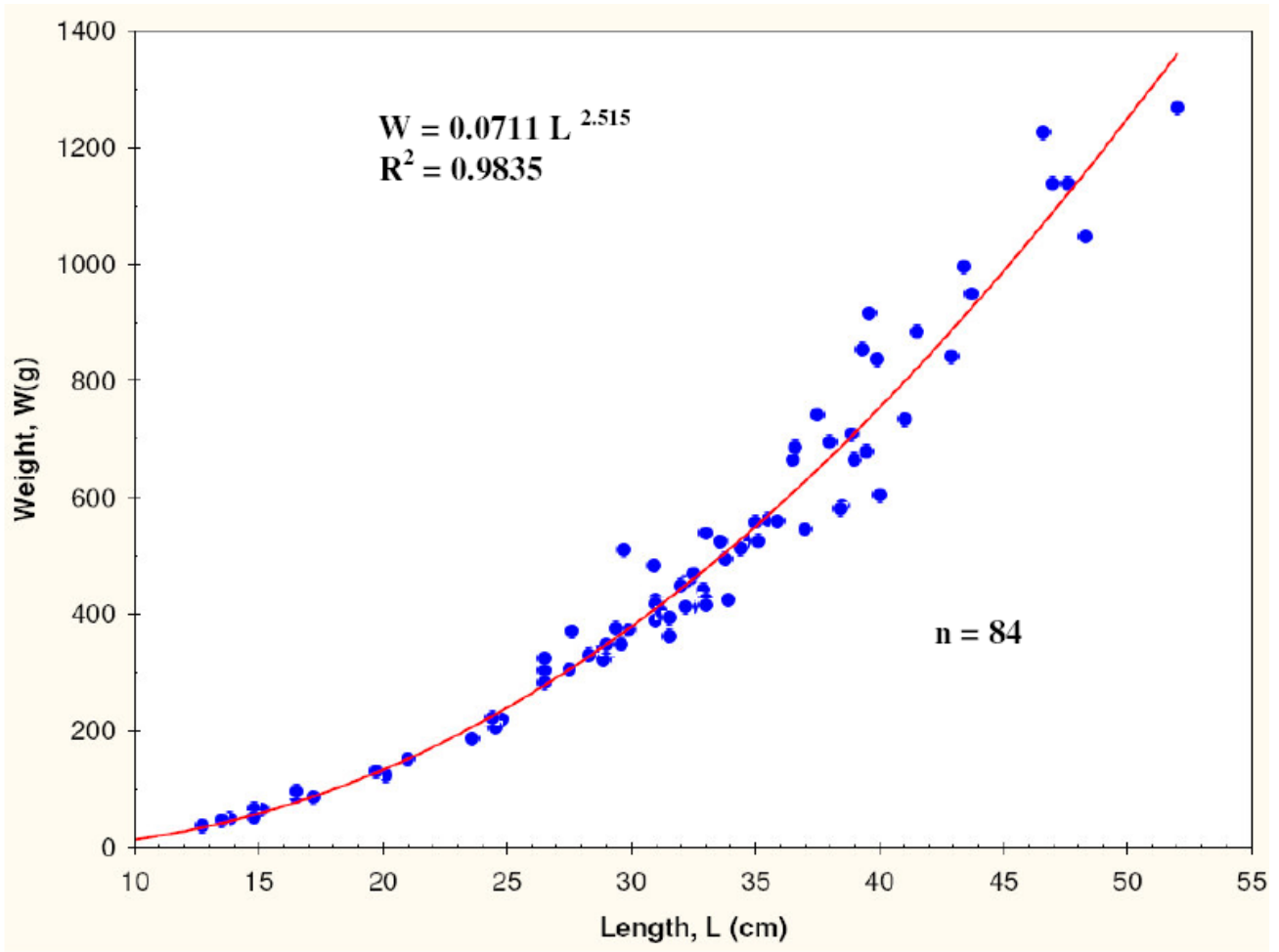

Fig. 4. Size-weight relationship of Balistes capriscus in Western Gulf of Guinea 
Plate A shows a typical first dorsal spine image which was used to age B. capriscus. The spines normally had two out-growths or 'arms' which had annual rings imprinted on them. These arms extended from separate focus where they were broad in shape and tapered towards the posterior tip. The annuli appeared as alternate dark and light bands when viewed in two-dimension or as alternate crest and trough when viewed in threedimension. Out of 74 spine slides, $66(89.2 \%)$ were readable. The lengths of aged individuals ranged from 127 to $415 \mathrm{~mm}$, ages 5-6 and 10-11 individuals were the dominant and least age classes, respectively, $71.2 \%$ of the fish were less than 7 years old and average percentage error for ageing was $8.1 \%$.

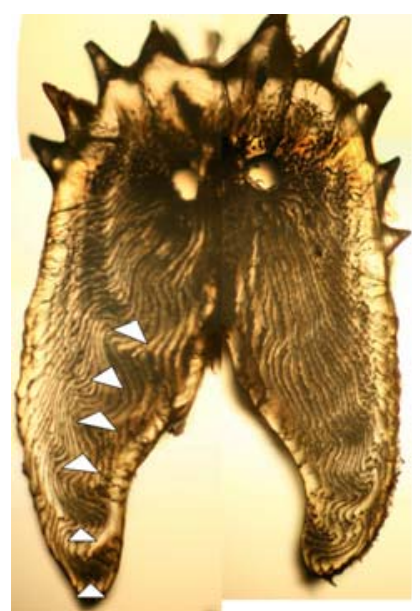

Plate A. Slide of first dorsal spine showing annual growth rings

\section{Growth estimation model}

Fig. 5 shows the relationship between total length $(\mathrm{mm})$ and age of Balistes capriscus from the Western Gulf of Guinea. The plots represent von Bertalanffy growth relation derived from observed data. The growth equation was fitted to the observed age at length data obtaining the following growth parameters: theoretical length $\left(L_{\infty}\right), 450.81 \pm 14.07 \mathrm{~mm}$ and growth coefficient $(K), 0.21$ year $^{-1}$.

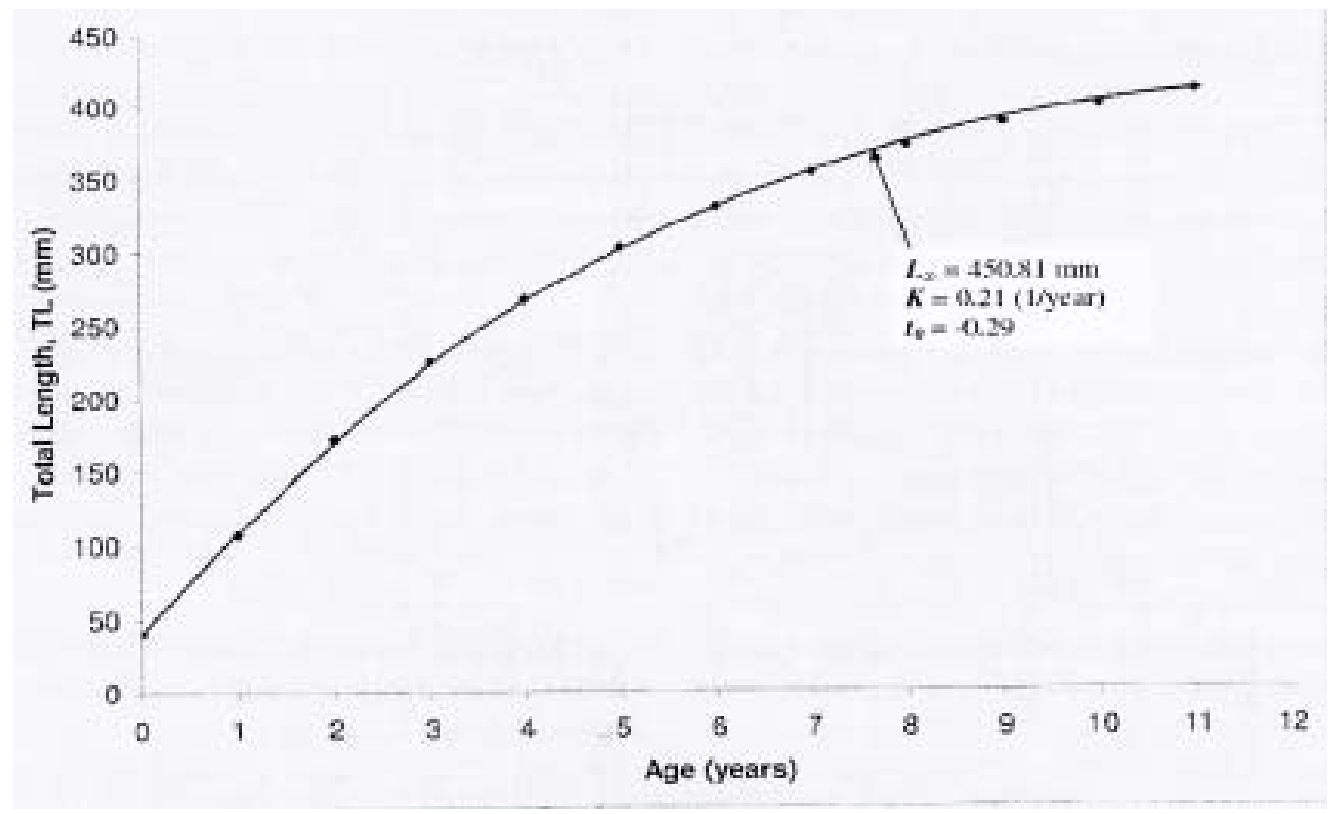

Fig. 5. Von Bertalanffy growth curve of Balistes capriscus (grey triggerfish). Growth parameters from observed data

\section{Back calculation}

The power function of the total length-spine radius relationship of B. capriscus was:

$$
T L=173.42[S R]^{1.2696}
$$

where $T L(\mathrm{~mm})$ is the total length and $S R(\mathrm{~mm})$ is the spine radius. Table 1 shows the back-calculated total lengths $(\mathrm{mm})$ at age for grey triggerfish from the Western Gulf of Guinea using the TL-SR relationship. Table 1 also indicates a calculated mean length of fish at annulus, total spines considered for a particular annulus 
based on the number of specimens in various age groups and estimated growth increment from successive annuli in B. capriscus. The variation in fish lengths at annuli 1,2,5,6 and 7 were much higher, whereas that of annuli 9 and 10 were lower. Back-calculated lengths in this study for grey triggerfish ranged from 140.6 $\mathrm{mm}$ for age 1 fish to $474.6 \mathrm{~mm} T L$ for fish 11 years old. The annual increments in fish length were much wider from $140.6 \mathrm{~mm}$ to $47.0 \mathrm{~mm}$ at the initial annuli stages, and tend to be smaller from $33.4 \mathrm{~mm}, 31.9 \mathrm{~mm}$ to $44.1 \mathrm{~mm}$ towards latter formed annuli and much smaller at older age from $14.0 \mathrm{~mm}$ to $12.2 \mathrm{~mm}$ at annuli 10 and 11 increments for grey triggerfish.

TABLE 1

Back-calculated total lengths $(\mathrm{mm})$ at age of grey triggerfish from the Western Gulf of Guinea

\begin{tabular}{|c|c|c|c|c|c|c|c|c|c|c|c|c|}
\hline \multirow[t]{2}{*}{ Age } & \multirow[t]{2}{*}{$\mathbf{N}$} & \multicolumn{11}{|c|}{ Annulus } \\
\hline & & 1 & 2 & 3 & 4 & 5 & 6 & 7 & 8 & 9 & 10 & 11 \\
\hline 2 & 9 & 102.3 & 156.0 & & & & & & & & & \\
\hline 3 & 3 & 160.3 & 195.7 & 227.9 & & & & & & & & \\
\hline 4 & 10 & 130.6 & 171.2 & 218.6 & 253.8 & & & & & & & \\
\hline 5 & 13 & 120.4 & 164.7 & 223.2 & 258.6 & 285.3 & & & & & & \\
\hline 6 & 13 & 118.3 & 171.2 & 244.3 & 253.8 & 282.8 & 310.0 & & & & & \\
\hline 7 & 3 & 171.2 & 207.1 & 242.0 & 270.7 & 292.6 & 322.5 & 360.6 & & & & \\
\hline 8 & 3 & 166.8 & 209.4 & 249.1 & 278.0 & 305.0 & 352.9 & 378.7 & 412.8 & & & \\
\hline 9 & 6 & 145.3 & 204.8 & 244.3 & 287.7 & 320.0 & 370.9 & 399.6 & 434.1 & 447.5 & & \\
\hline 10 & 4 & 145.3 & 198.0 & 239.6 & 275.5 & 307.5 & 345.2 & 386.5 & 412.8 & 442.1 & 458.3 & \\
\hline 11 & 2 & 145.3 & 198.0 & 246.7 & 287.7 & 325.0 & 378.7 & 407.5 & 423.4 & 455.6 & 466.4 & 474.6 \\
\hline Total & 66 & 66 & 66 & 57 & 54 & 44 & 31 & 18 & 15 & 12 & 6 & 2 \\
\hline Weighted & & 140.6 & 187.6 & 237.3 & 270.7 & 302.6 & 346.7 & 386.6 & 420.8 & 448.4 & 462.4 & 474.6 \\
\hline mean $\pm 1 S D$ & & \pm 22.5 & \pm 19.7 & \pm 11.1 & \pm 14.0 & \pm 16.5 & \pm 26.8 & \pm 18.3 & \pm 10.2 & \pm 6.8 & \pm 5.7 & - \\
\hline $\begin{array}{l}\text { Annual } \\
\text { increment }\end{array}$ & & 140.6 & 47.0 & 49.7 & 33.4 & 31.9 & 44.1 & 39.9 & 34.2 & 27.6 & 14.0 & 12.2 \\
\hline
\end{tabular}

Comparison of growth performance of grey triggerfish

Table 2 shows the reported growth parameters of grey triggerfish and their derived growth performance $(\varnothing ')$ during dominance and collapse periods in West African waters. The growth of B. capriscus in the Western Gulf of Guinea had not changed significantly for the last two-and-half decades. The growth performance obtained in this study was 2.63 for B. capriscus.

TABLE 2

Parameters of the von Bertalanffy's growth function of Balistes capriscus obtained from literature and estimates of growth performance, $\varnothing^{\prime} . L_{\infty}$ and $K$ for this study were obtained from observed data. All $\varnothing^{\prime}$ were calculated in this study. Dominance phase of triggerfish occurred in 1970s and early 1980s; and collapse phase occurred in the late 1980s.

\begin{tabular}{llllll}
\hline Area & $\mathbf{L}_{\infty}(\mathbf{c m})$ & $\mathbf{K}\left(\mathbf{y r}^{-1}\right)$ & $\boldsymbol{\phi}^{\prime}$ & Remarks & Source \\
\hline Senegal & 37.5 & 0.45 & 2.80 & Male & Caverivière (1982) \\
Senegal & 38.0 & 0.35 & 2.70 & Female & Caverivière (1982) \\
Senegal & 40.7 & 0.31 & 2.71 & Both sexes & Caverivière (1982) \\
Côte d'Ivoire & 41.0 & 0.11 & 2.27 & Both sexes & Caverivière (1982) \\
Ghana & 40.8 & 0.43 & 2.85 & Both sexes & Ofori-Danson(1989) \\
Ghana & $45.1 \pm 1.4$ & $0.21 \pm 0.02$ & 2.63 & Both sexes & Present study \\
\hline
\end{tabular}

The mean of $L_{\infty}$ for B. capriscus for both sexes in Senegal, La Côte d'Ivoire and Ghana is $40.83 \pm 0.09 \mathrm{~cm}$ (SE) for $95 \%$ confidence interval, whereas the $L_{\infty}$ for $B$. capriscus in this study is $45.1 \pm 1.4 \mathrm{~cm}(\mathrm{SE})$. 


\section{Discussion}

The results of the present study indicate a distribution of grey triggerfish in coastal waters of countries (Benin, Togo, Ghana and La Côte d'Ivoire) bordering the Western Gulf of Guinea. Grey triggerfish distribution from Senegal to Nigeria in the late 1970s along the West African coast had earlier on been documented in Longhurst \& Pauly (1987), Koranteng et al. (1996) and Saetersdal et al. (1999). Thus, despite the decline of triggerfish in the Western Gulf of Guinea for nearly two decades, the distribution of grey triggerfish resource had not changed. In terms of depth range, grey triggerfish in the Western Gulf of Guinea occurred between the depth of $23 \mathrm{~m}$ and $60 \mathrm{~m}$ (Fig. 2). The depth distribution results of the species were not much different from the depth range 15-50 m, which was reported during grey triggerfish abundance in 1980-81 (Ofori-Adu \& Koranteng, 1993).

The size distribution of grey triggerfish in this study showed that $27.0-31.9 \mathrm{~cm}$ and $32.0-36.9 \mathrm{~cm}$ TL were the modal size classes for the grey triggerfish samples obtained in May 2005 during the Nansen survey. This is comparable to the previously reported modal size of grey triggerfish in Ghanaian coastal waters which stood at $18.0 \mathrm{~cm} F L$ in June from sample size of 194, $22.5 \mathrm{~cm}$ FL in July from sample size of 152 and 18.0 $23.0 \mathrm{~cm} \mathrm{FL}$ in August from sample size of 364 (Ofori-Danson, 1981). It is likely that the modal size classes, $27.0-31.9 \mathrm{~cm}$ and $32.0-36.9 \mathrm{~cm} T L$ of grey triggerfish dominate in the Western Gulf of Guinea waters from May to August every season.

The maximum size $(520 \mathrm{~mm} T L)$ of grey triggerfish observed in this study was higher than that previously reported in the early 1980s, which was $350 \mathrm{~mm} \mathrm{FL}$ in coastal waters of Ghana (Ofori-Danson, 1981). The present increase in maximum size might be due to the fact that grey triggerfish had not been a target fish for the artisanal fishery since its collapse in the late 1980s, and, therefore, the fish is able to survive for quite a relatively longer period of time before exposure to risks of fishing mortality. The maximum size observed in this study might be due to the length-data pooled from Benin to La Côte d'Ivoire (i.e., Western Gulf of Guinea). Also, Ofori-Danson (1981) used fork length of the fish to estimate maximum size, whereas total length was used in this study.

Gear selectivity probably might explain the difference in maximum length, as specimens for this study were collected during the survey using a "Harstad" and "Åkrahamn" pelagic trawls and "Gisund" super bottom trawl (Mehl et al., 2005), and that of the previous workers were beach seine, "ali", "poli" and set nets. The size-weight relationship of grey triggerfish obtained in the present study was not different from that of Ofori-Danson (1981) in Ghanaian coastal waters, even though the triggerfish specimens were pooled from La Cote d'Ivoire to Benin waters in this study. The size-weight equation showed that the exponent of length is sufficiently close to 3.0 , a situation which indicates that B. capriscus grows isometrically.

The maximum age of triggerfish in this study was 11 years, although Johnson \& Saloman (1984) reported higher ages of 12 and 13 years in the Gulf of Mexico. This may suggest that the trawls excluded older fish from the samples. The back-calculated lengths for grey triggerfish in this study were much more comparable to results obtained by Johnson \& Saloman (1984) on the same fish species from northeastern Gulf of Mexico. Annual increment patterns observed in the dorsal spine growth studies in grey triggerfish indicated a faster growth at juvenile stage but slowing down at adult stage. A similar pattern of growth was observed in queen triggerfish from the U.S. Virgin Islands and Puerto Rico (Manooch III \& Drennon, 1987).

The asymptotic length $\left(L_{\infty}\right)$ was greater, and rate of growth $(K)$ slower than previously reported for the grey triggerfish in Ghana (Table 2). Nevertheless, the rate of growth was comparable to that previously reported for grey triggerfish in La Côte d'Ivoire $\left(0.11\right.$ year $\left.^{-1}\right)$ and Senegal $\left(0.31\right.$ year $\left.^{-1}\right)($ Caverivière, 1982). The high $L_{\infty}$ in this study might have been obtained as a result of the length-age data pooled for the specimens in the Western Gulf of Guinea. This indicates that the rate of growth and maximum size of grey triggerfish in the Western Gulf of Guinea had not changed despite the decline of the fish species in catches of West Africa for nearly two decades.

\section{Acknowledgement}

The author wishes to thank the Marine Fisheries Research Division (MFRD), Tema, and Norwegian Agency for Development Cooperation (NORAD), for providing logistics for the sample collection during Dr Fridtjof Nansen Survey 2005 in the Western Gulf of Guinea. The facilities used at the Center for Tropical Marine Ecology, Bremen are also acknowledged. 


\section{References}

Caverivière A. (1982). The West African triggerfish (Balistes carolinensis). Biology, proliferation and potential exploitation. Ocean. Acta 5 (4): 453-459.

Dulèiæ J., Kršinić F., Kraljević M. and Pallaoro A. (1997). Occurrence of fingerlings of grey triggerfish, Balistes carolinensis Gmelin, 1789 (Pisces: Balistidae), in the Eastern Adriatic. Ann. An. Istrske Mediter. Stud. (Hist. Nat.). 7: 271-276.

Essuman K. and Diakit B. (1990). Utilization of triggerfish (Balistes carolinensis = B. capriscus) in Ghana and Senegal. FAO Fisheries Circular No. 828. 23 pp.

FAO (2006). Fishery Statistics: Capture production 2004. FAO Fisheries Series No. 72, FAO Statistics Series No. 190. Vol. 98/1, 560 $\mathrm{pp}$.

FAO-ICLARM Fish Stock Assessment Tools (FiSAT) (December 2006). Available at http:// www.fao.org/fi/statist/fisoft/fisat/index.htm (last accessed 16 February 2007).

Gayanilo Jr., F. C. and Pauly D. (ed.) (1997). The FAO-ICLARM Stock Assessment Tools (FiSAT) Reference Manual. FAO Computerized Information Series (Fisheries) Vol. 8. FAO, Rome.

Johnson A. G. and Saloman C. H. (1984). Age, growth, and mortality of gray triggerfish, Balistes capriscus, from the northeastern Gulf of Mexico. Fish. Bull. 82 (3): 484-491.

Koranteng K. A. (1998). The impacts of environmental forcing on the dynamics of demersal fishery resources of Ghana. (PhD Thesis.) University of Warwick. 377 pp.

Koranteng K. A., McGlade J. M. and Samb B. (1996). A Review of the Canary Current and Guinea Current Large Marine Ecosystems. In ACP - EU Fisheries Research Report No. 2. (ISSN 1025), pp. 61-81.

Lobel P. S. and Johannes R. E. (1980). Nesting, eggs, and larvae of triggerfishes (Balistidae). Env. Biol. Fish. 5 (3): 251-252.

Longhurst A. R. and Pauly D. (1987). Ecology of Tropical Oceans. Academic Press: New York, London, Sydney, Toronto. 407 pp.

Manooch III C. S. and Drennon C. L. (1987). Age and growth of yellowtail snapper and queen triggerfish collected from the U.S. Virgin Islands and Puerto Rico. Fish. Res. 6: 58-68.

Mehl S., Alvheim O. and Quaatey S. N. K. (2004). Surveys of the fish resources of the Western Gulf of Guinea (Benin, Togo, Ghana, Cote d'Ivoire). Survey of the pelagic and demersal resources 14 May-08 June 2004. NORAD-FAO/UNDP project GCP/INT/730/NOR. Cruise reports Dr. Fridtjof Nansen, Institute of Marine Research, Bergen, Norway. 59 pp.

Mehl S., Olsen M. and Bannerman P. O. (2005). Surveys of the fish resources of the Western Gulf of Guinea (Benin, Togo, Ghana, Cote d'Ivoire). Survey of the pelagic and demersal resources 03-29 May 2005. NORAD-FAO/UNDP project GCP/INT/730/NOR. Cruise reports Dr. Fridtjof Nansen, Institute of Marine Research, Bergen, Norway. 63 pp.

Mensah M. A. and Quaatey S. N. K. (2002). An Overview of Fishery Resources and Fishery Research in the Gulf of Guinea. In The Gulf of Guinea Large Marine Ecosystem: Environmental Forcing and Sustainable Development of Marine Resources. (J. M. McGlade, P. Cury, K. A. Koranteng and N. J. Hardman-Mountford, ed.). Elsevier, Amsterdam.

Moore D. (1967). Triggerfishes (Balistidae) of the western Atlantic. Bull. Mar. Sci. 17 (3): 689-722.

Ofori-Adu D. W. (1987). A Note on the Problem of the Triggerfish Fishery in Ghana. Marine Fisheries Research, Special Paper No. 1. Fisheries Department, Research and Utilization Branch, Tema, Ghana. p. 7.

Ofori-Adu D. W. (1994). Where is Ewura Efua - The Triggerfish? The Fisherman. A Bi-annual Newsletter of the Fisheries Department. Ministry of Food and Agriculture, Ghana. pp. 13-16.

Ofori-Adu D. W. and Koranteng K. A. (1993). Occurrence of demersal fish species off Winneba and Saltpond: Their abundance and distribution in relation to the marine environment. Mar. Fish. Res. Rep. No. 9. Tema Ghana. 88 pp.

Ofori-Danson P. K. (1981). The Biology of the Triggerfish, Balistes capriscus in Ghanaian Waters. (MSc Thesis.) University of Ghana, Legon. 98 pp.

Ofori-Danson P. K. (1989). Growth of Grey Triggerfish, Balistes capriscus, based on Growth Checks of the Dorsal Spine. Fishbyte 7 (3): 11-12.

Pauly D. and Munro J. L. (1984). Once more on the comparison of growth in fish and invertebrates. ICLARM Contribution No. 195. Fishbyte 2(1): 21.

Saetersdal G., Bianchi G., Stromme T. and Venema S. C. (1999). The Dr. Fridtjof Nansen Programme 1975-1993. FAO Fish. Tech. Paper 391.

Sazonov Yu. G. and Galaktionova A. I. (1987). Some data on the morphometrics of the grey triggerfish, Balistes carolinensis, of the central-eastern Atlantic. J. Ichthy. 27(3): 173-176.

Stromme T., Saetersdal G. and Gjosxter H. (1982). Preliminary report on surveys with the R/V Dr Fridtjof Nansen in West African waters in 1981. CECAF. Working Party on Resource Evaluation. Ses. 6. Dakar 2-6 February 1982. Bergen.

Stromme T. (1983). Final Report of the R/V Dr. Fridtjof Nansen Fish Resource Surveys off West Africa from Agadir to Ghana May 1981-March 1982. A joint NORAD FAO/UNDP project. Institute of Marine Research, Bergen, Norway. 